\title{
The Reorganization of the Stanford University Libraries
}

Mr. Grieder is associate director, Stanford University Libraries.

$I^{N}$ a SURVEY of the Stanford University Libraries published in 1947 one of the weaknesses upon which the surveyors dwelt at length was a rapid deterioration of the bonds which held together the main library and the twenty-four special and departmental libraries. They noted a strong tendency toward decentralization, which had already withdrawn from the effective jurisdiction of the library administration a large and important segment of the collections and a considerable portion of the University's total expenditures for library purposes. ${ }^{1}$ This trend toward autonomy in the establishment and operation of subject libraries had developed in contradiction to action taken by both the Academic Council and the Board of Trustees in 1925. ${ }^{2}$ Legally the Director of Libraries was in a strong position; actually, of twenty-four departmental and professional school libraries four were staffed by the main library and therefore under a fairly direct control; six were staffed from departmental budgets, and fourteen were unstaffed, or managed by secretaries or students having no con-

\footnotetext{
${ }^{1}$ Wilson, Louis R, and R. C. Swank, Report of a Survey of the Library of Stanford University. Chicago, ALA, ${ }^{1947}$, p. 61-65, I 14-16. Questions relating to special libraries are also discussed in chapters devoted to finance, personnel, and other aspects of library
operations.

2 Stanford University, Trustees Manual, 1937, p. r99. "He the Director of Libraries, shall have custody of all books, etc. belonging to the University Library or to Departmental Libraries . He shall have control of all assistants who shall be employed in the administration of the Library... Librarians or cura tors of departmental or special libraries employed primarily for the care and administration of such shal be nominated for appointment by the Director of Li. braries and shall be under his general supervision and
}

nection with the main library. In September, 1946 the Hoover Library was placed directly under the chairman of the Hoover Institute and Library; the Medical Library showed a strong tendency to pull away; and a general feeling of dissatisfaction with the existing relationships was evident in many departments and schools. ${ }^{3}$ Control by the central library administration was regarded in many quarters as unnecessary, and sometimes as a positive hindrance to effective library operation.

This breakdown in organization was attributed primarily to a lack of machinery for the proper administration of the outlying collections and of certain centralized functions, especially the allocation and expenditure of book funds, budget planning and accounting, and public services. ${ }^{4}$ Perhaps the most fundamental weakness was the concentration of responsibility in the director's office. In addition to direct supervision of six central divisions and twenty-four special libraries, he was personally responsible for all budgeting and accounting, interlibrary loans, exchanges, and departmental and university relationships of all kinds.

The Survey proposed an immediate reorganization in which an associate librarian would assume responsibility for the existing divisions in the main library, and an assistant librarian would supervise the operation of all departmental and school libraries. The latter were to be grouped into three divisions: Social Sciences, Biological Sciences, and Physical Sciences and

3 Survey, p. $63-64$, I $14-16,128 \cdot 29$.

4 Ibid., p. $45 \cdot 58,64-65,70-72$. 
Engineering, with the Lane Medical Library and the Hoover Library as separate divisional entities. For the more distant future, when better integration of the divisions could be effected, a scheme having seven divisions was proposed, with an associate librarian sharing central administrative duties. These divisions were designated as Central Processing, Central Service, Hoover Library, Humanities, Social Science, Biological Science (which would include the Lane Medical Library), and Physical Science and Engineering. ${ }^{5}$

It will be seen that the surveyors were much preoccupied by the proliferation of special libraries, the irregular and uncertain character of their financing, their tendency to escape the jurisdiction of the library administration, and the resulting inefficiency of all library functions. This paper is an account of what Stanford has done since 1947 to reestablish effective administrative control over existing collections, to coordinate their acquisitional and service functions, and to insure that any new libraries will be established on sound foundations and with a logical and clearly defined relationship to the whole library system.

\section{The Divisional Organization at Stanford}

In September, 1949 a partial reorganization of the Stanford libraries took effect, by which every library in the University was placed in a definite relationship to the system as a whole, as illustrated on the accompanying organization chart. The four central divisions-Order, Catalog, Circulation, and Special Collections-remained virtually unchanged, though the first has since been renamed the Acquisition Division. The Reference Division, which became the Reference and Humanities Division, had no distinct change in its func-

5 Ibid., p. $65-69$, $116-119$. Charts for the two plans appear on pages 67 and 69 . tions, but was henceforth considered one of the subject divisions, with a view to its ultimate conversion into a Humanities Library. Certain special subject responsibilities were attached to it and the Music Library and a small German collection were assigned to its jurisdiction.

The most radical step in this reorganization was the grouping of the small subject collections into three new divisions. The Social Science Division embraced the Documents Library, the Education Library, the Hopkins Transportation Library, the Journalism Library and the West Memorial Library in political science. The Biological Science Division included seven related libraries, and has since absorbed an eighth. The Science and Engineering Division comprised seven technical libraries, of which two, the Mathematics and Physics Libraries, have since merged. The Lane Medical Library formed a ninth division. A chief librarian was appointed to head each division, the incumbent being in most cases the librarian of the largest component collection. The Business, Law, Food Research, and Hoover Libraries retained their autonomous status, which consists essentially in being financed from school or institute budgets. The University Library performs certain functions, such as ordering and cataloging, for most of these libraries, but they are not under its jurisdiction in a statutory sense.

The divisional plan as it has evolved in the past ten years in the libraries of the University of Colorado, the University of Nebraska or Washington State College originated primarily as a device to strengthen the services of the library. It is a compromise intended to retain the administrative efficiency of the centralized collection while securing at least in part the advantages of convenience, expert subject librarianship, and faculty interest which special libraries are intended to provide. 
STANFORD UNIVERSITY LIBRARIES ORGANIZATION CHART

STANFORD UNIVERSITY LIBRARIES ORGANIZATION CHART
September I, I951


It can conceivably operate as a centralizing or as a decentralizing process, depending on the nature of the library to which it is applied. At Stanford the divisional plan was essentially an effort to reintegrate the libraries in an administrative sense. It has had no distinct effect as regards physical relocation or reorganization of the collections, which for the most part is contingent on the realization of a building program adapted to a new alignment of the library's resources.

The divisional organization at Stanford has achieved substantial results in eliminating, or at least alleviating, the evils at which it was aimed, and it has brought many positive benefits. Its results may be summarized as follows:

I. It has permitted decentralization of many administrative duties, the division chiefs now assuming responsibility for the libraries under their jurisdiction in such matters as staff schedules, service policies and procedures, budget planning, routine faculty contacts, and other administrative functions.

2. It has encouraged the growth of a competent administrative group, closely associated with various faculties, to represent the interests of the subject libraries and the faculties they serve in planning the over-all library program. The increased independence and larger responsibilities of the division chiefs have been a great stimulus to their professional growth and to their interest in the library as a whole as well as in their own divisional library activities. The Administrative Council of division chiefs meets regularly with the Director of Libraries to discuss problems of common interest and to plan changes in policy and procedure.

3. It has fostered the coordination of acquisition programs and service functions among libraries with similar interests and has tended to place emphasis on the advantages of closer relationships. The recent merger of the Mathematics and Physics Libraries illustrates the readiness of faculty members to recognize these advantages and their willingness to accept administrative simplification if they are confident that their own interests are appreciated and protected.

4. It has assured at least some regular professional supervision for every library, even though full-time librarians can be provided only-for the larger collections.

5. It has facilitated the centralization of book funds, accounting, binding, serial records, and cataloging in the main library, the formulation of uniform service programs, and the unification of the library budgets.

The plan as it has finally developed conforms to neither of the schemes proposed by the surveyors. It most closely resembles the second, but the Order, Catalog, Circulation and Special Collections Divisions retain their identities, the Hoover Library remains autonomous, and the Lane Medical Library is a division rather than a part of the Biological Science group.

\section{The Classification of Libraries}

An attempt has recently been made to classify the special libraries at Stanford on the basis of certain descriptive criteria. It became necessary during the past year to formulate a procedure for setting up a proposed new library. A very brief consideration led to the conclusion that some definition of its ultimate size and character would be required before any rational plan could be developed. This in turn led to a review of existing libraries. They fell into two main types, which were finally characterized as branch libraries and departmental libraries. These classes were distinguished only after the criteria had been listed, and libraries were classified on the basis of their conformity to one or the other set of standards. In general, branch libraries are those having the following characteristics:

I. The major (not necessarily all) resources of the University Libraries in appropriate subject fields are housed in these libraries. 
2. They are intended to be indefinitely cumulative, except as financial conditions, space, or other circumstances may force limitations.

3. New acquisitions in the subjects covered are automatically sent to these libraries regardless of the funds from which they are purchased; e.g., all items classed in Dewey 370 go to the Education Library; all in 620 and 699 go to Engineering.

4. Branch libraries are generally expected to have full catalogs (i.e., including subject cards and other secondary entries) for their holdings.

5. They are normally staffed by professional librarians.

6. They maintain, as far as possible, a full schedule of open hours.

7. Cards in the main catalog for their holdings are generally stamped with location marks.

Six of the existing libraries were designated as branch libraries, since they conform fairly well to the above criteria: Biology, Music, Engineering, Mineral Sciences, Education, and the Lane Medical Library.

The criteria for departmental or working libraries are in large measure negatives of those given above:

1. Departmental libraries are limited to the most frequently used works in their fields and are restricted in size.

2. They are not indefinitely cumulative. Older and less used materials are transferred to the main stacks or to a branch library.

3. Only those acquisitions specifically requested are sent to them. Such requests may come from a faculty member or a divisional librarian, and may refer to new purchases or to books already in the main library.

4. Normally only an author catalog and shelf-list are provided.

5. Non-professional assistants, part-time graduate students, or departmental secretaries may supervise departmental libraries, under the direction of members of the divisional staff.

6. Departmental libraries may operate on restricted schedules of open hours, de- pending on the needs of the faculties which they serve.

7. Cards in the main catalog for their holdings are not stamped. Books are charged to them from the Circulation Division and are considered loans from the main library. This insures mobility and ease of handling.

In practice a third class of library is recognized, the permanent special collection. This is usually a static or slowlygrowing library, often endowed, which by the terms of the founding gift or for some other strong reason is likely to remain forever separate from the rest of the collections. The Felton Library of English and American Literature must legally remain a separately-housed reference collection. The library of the Hopkins Marine Station at Pacific Grove is about roo miles from the campus. It is heavily endowed and must be used for research in marine biology. While it is not a branch library by definition it will therefore remain a separate special library.

It should be emphasized that the criteria for branch or departmental libraries as they are listed above cannot be rigidly applied in every case. They do in a general sense express a pattern and outline a set of objectives, and in the case of a new library they define the essentials of its organization according to the type of library it is intended to be. A decision on the latter point must take into account the financial support available, the subject field to be covered, the existing libraries in related fields, and all other considerations which might affect its operation and its relationship to the rest of the Stanford Libraries.

\section{The Establishment of New Libraries}

One of the principal causes of disorganization pointed out in the Stanford survey was the unregulated and unauthorized growth of special subject collections, some- 
times through gifts and under restrictions which had never been accepted by the library. In some cases their very existence was unknown to the central library administration for years. These collections were often unsystematically built, poorly cataloged-if at all-and without any effective supervision. They had no defined relationship to the rest of the libraries. The processing which some of them needed was a serious drain on library resources after the divisional consolidation, because of their considerable size and the faulty records resulting from lack of professional attention. Their financial support was often uncertain and came from various sourcessupply and expense budgets, endowments, transfers from gift funds, expendable gifts, special university grants, or the library budget. In at least one case student fees were used. It was virtually impossible to isolate library expenditures from other categories of departmental accounting.

When a new library was proposed it was considered essential that it be established on a solid financial basis, with proper bibliographical and business records, under competent professional supervision, and with a definite plan regarding its size and scope. In order to insure this a code of regulations was drawn with the approval of the Faculty Library Committee and the president of the university. The essentials of this code are as follows:

I. Any department may establish with the approval of the director of University Libraries a departmental library as a service point of the main library, conforming in general to the seven criteria outlined for such collections. The purpose, content, and size of these collections will be subject to review each year by the director. No specialized staff will be provided, although arrangements must be completed and funds made available for student or other help to attend the library and make the books readily available for at least seven hours each day
Monday through Friday, and three hours on Saturday, except during vacation periods. In effect, the books in these libraries will be on loan from the main collection and therefore must be kept accessible to the whole university constituency for a reasonable time each week.

2. Branch libraries may be established, or departmental libraries may become branch libraries, with the approval of the director of University Libraries, the Faculty Library Committee, and the president. In general they will operate according to the criteria set up for such collections.

3. All general university funds and restricted gift funds earmarked for departmental library purposes will be assigned to the budget of the University Libraries. In addition, all books and other library materials given to the departments will be assigned to the custody of the University Libraries. Any terms or conditions restricting the disposition of gift funds or materials will be referred to the director of University Libraries for approval by him and by the president's office before the gifts are accepted.

These provisions are primarily concerned with administrative arrangements. In practice, faculty and library opinion regarding further dispersion of the collections is very influential in discussions regarding special libraries. The plan for remodeling the main library-still in the paper stage-will allow the organization of certain subject reading rooms which should largely eliminate the need for new special libraries and perhaps make possible the absorption of some smaller ones now in existence.

As the chart shows, the physical and biological sciences are well equipped with special facilities and the only new proposals in these fields have involved small laboratory collections. Of the components in these two divisions only the Engineering Library is in the main building, and lack of space as well as considerations of distance 
will prevent any major consolidation unless a unified science library is built at some point convenient to the faculties in these subjects.

The humanities and social sciences are much in need of better library facilities and will receive first consideration in the development of building plans for the main library. These two divisions are as yet administrative conveniences rather than coordinated groups of closely related libraries. The probability that there will some day be adequate reading rooms and better coordinated acquisitional and service programs for these divisions must be an important factor in determining whether new special collections shall be permitted to grow outside the main library in subject fields which they cover.

It is too early to assert that the existing arrangement of divisions and the stipulations regarding special libraries represent a final stage in Stanford's thinking. It can only be said that they have up to this time been effective in combating some of the most serious weaknesses noted in the survey, and that within their framework there seems to be the possibility of an orderly and effective development of Stanford's collections and services.

\section{Expanding the Card Catalog}

(Continued from page 245)

prompt action. If this is done, there will be less to catch up on at the time of the move. At this time, there should be, nevertheless, an automatic inspection of trays, with elimination of any trays that are defective in body of the tray, label holder, or handle. These should be sent out regularly for repair as the work progresses.

A sufficient supply of label holder screws should be on hand, and any that turn without gripping should be replaced. In order to be effective, a replacement screw must be larger than the one replaced; old screws from the catalog should not be used under any circumstances. Our carpenter shop has been helpful in determining the size of screw needed, as well as being the source of supply.

Bent rods should be straightened; this can be done easily with a little practice. For this catalog, a supply of nuts and bolts is needed to fasten in the metal square at the back of the tray that frequently becomes detached. An extra supply of the metal part should be on hand to replace any that have been lost.

\section{Method for Complete Transfer of a Catalog}

The complete transfer of an old catalog to new equipment is in some ways less of a problem than the process of expansion. Such a procedure was experienced here when the move from Low Library to the present building took place. The planning followed the method related above, but tray contents for the new catalog were indicated by upright cards inserted at appropriate points in the original catalog. These cards carried the label statement in each instance. This preliminary work consumed a month of the time the moving of the book collections was under way. During that time, labels were made and put in place in the new catalog. When the time came for removal of the catalog to its new quarters, the process was one of simple transfer of tray contents and consumed only a few hours. It is not recalled that the catalog was used in transit, although tradition has it that encyclopedias were consulted en route. In any case, catalog trays were out of use for a brief time only. 